\title{
Report of cases in patients with acute herpetic neuralgia using a Mangifera indica extract
}

\author{
Beatriz Garrido-Suárez, ${ }^{*}, 1,3$ Gabino Garrido, ${ }^{2}$ Rene Delgado, ${ }^{1}$ \\ Fe Bosch, ${ }^{3}$ María del C. Rabí, ${ }^{3}$ Camilo E. Hernández ${ }^{4}$
}

\author{
${ }^{1}$ Laboratorio de Farmacología Molecular, Centro de Investigación y Desarrollo de \\ Medicamentos, Cuba, \\ ${ }^{2}$ Departamento de Química y Farmacia, Facultad de Ciencias, Universidad Católica del \\ Norte, Chile, \\ ${ }^{3}$ Clínica del Dolor, Hospital Docente Clínico Quirúrgico 10 de Octubre, Cuba, \\ ${ }^{4}$ Servicio de Dermatología Hospital Docente Clínico Quirúrgico 10 de Octubre, Cuba.
}

Revista Brasileira de Farmacognosia Brazilian Journal of Pharmacognosy 21(6): 1111-1117, Nov./Dec. 2011

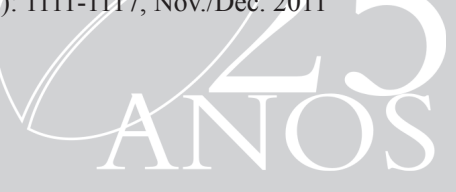

\begin{abstract}
It has been accepted that neuroinflammation, oxidative stress and glial activation are involved in the central sensitization underlying neuropathic and inflammatory pain. Vimang ${ }^{\circledR}$ is the brand name of an aqueous extract of Mangifera indica L., Anacardiaceae, traditionally used in Cuba for its antioxidant, antiinflammatory, analgesic, and immunomodulatory properties. In the present study, we determined the possible effects of Vimang formulations in acute herpes zoster $(n=12)$ patients, that received a daily dose of $1800 \mathrm{mg}$ of extract (two coated Vimang tablets, $300 \mathrm{mg}$ each, three times daily before meals) associated to low doses of amitriptyline (10-25 $\mathrm{mg} / \mathrm{d})$. In addition to the tablets, they utilized compresses containing Vimang dissolution at $2 \%$ on skin lesions for thirty days. The average daily pain score using a Likert scale and variations in concomitant drug daily dosage were determined. The analgesic effect was observed from week $1(p<0.001)$ with respect to baseline data and none showed post-herpetic neuralgia. Significant reduction of antidepressant medication $(p<0.01)$ and analgesic rescue dosages $(p=0.0035)$ with respect to the initial daily dosage were showed. No adverse events were reported. The results obtained in this report of cases suggest that Vimang supplementation might be beneficial to prevent and treat neuropathic pain.
\end{abstract}

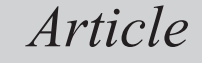

Received 9 Mar 2011 Accepted 4 May 2011 Available online 8 Jul 2011

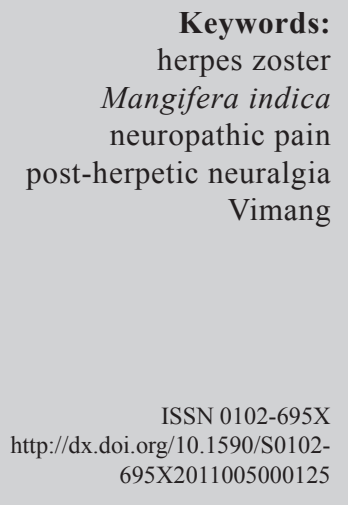

\section{Introduction}

Varicella zoster virus (VZV) is the neurotropic human alpha-herpes virus. Primary infection produces chickenpox (varicella) (Steiner et al., 2007). After acute herpes infection, VZV becomes latent in cranial nerve, dorsal root, and autonomic nervous system ganglia along the entire neural axis. Virus reactivation produces shingles (zoster). Herpes zoster (HZ) is characterized by severe inflammatory and neuropathic pain and rash restricted to 1-3 dermatomes (Oaklander, 2008). In more than $40 \%$ of patients over age 60 , herpetic neuralgia persists for months and years and then this pain is denominated post-herpetic neuralgia (PHN) and it is an intractable form of neuropathic pain often seen in pain clinics (Rowbotham \& Petersen, 2001). PHN is the more common complication of the acute herpes zoster; the elderly and those with a severe immunological deficit are at great risk (Kotani et al., 2004). The established PHN is often accompanied by physical and social disability, psychological distress and increased health care utilization (Kotani et al.,
2004; Steiner et al., 2007). It has been suggested that the prevalence of PHN is proportional to the degree of acute pain and severity of the inflammation and neural injury in acute herpes zoster (Dworkin et al., 2008). Then, the treatment in acute disease should be focussed at pain relief, viral replication inhibition, inflammation control and neural protection (Steiner et al., 2007). Many attempts have been made to prevent the onset of PHN, including early antiviral therapy, coadministration of antidepressants and epidural blocks with local anaesthetics and steroids (Wu \& Raja, 2008). However, there are poor results that confirm the efficacy of these strategies. On the other hand, there are some evidences on reactive oxygen species (ROS) and cytokine production play a role in neuropathic pain (Kim et al., 2004). Many studies in animal models and humans showed the anti-hyperalgesic and antiallodynic effects of ROS scavenging agents. Also, recent studies have established that the analgesic action of Vitamin E occurs through desensitization of neurons and inactivation of $N$-methyl-D-aspartate (NMDA) receptors in neuropathic rats (Kim et al., 2006; Gao et 
al., 2007).

It is of particular interest that central nervous system (CNS) neuroimmune response and spinal or supra-spinal glial activation have been involved in central sensitization, a pivotal mechanism in persistent pain (De Leo et al., 2006). Subsequently, neuroimmune activation has been proposed as a source of new targets for therapeutic intervention in neuropathic pain (Manning, 2006).

Vimang is the brand name of an aqueous extract of the mango (Mangifera indica L., Anacardiaceae) stem bark extract (MSBE) of selected varieties, which contains a definite mixture of components including polyphenols, triterpenes, phytosterols, fatty acids and microelements.

Different pre-clinical studies performed with this extract have demonstrated that it posses antioxidant, analgesic, anti-inflammatory, antiallergic and antiapoptotic effects (Núñez-Sellés et al., 2007). In clinical trials with different Vimang formulations have demonstrated antioxidant effects of tablets in HIV/AIDS patients (Pérez et al., 2003) and aging (Pardo-Andreu et al., 2006). The cream was also effective in dermatological diseases with an inflammatory component (Guevara et al., 2007). All of these pre-clinical and clinical effects were performed by the extract without toxicological or adverse events. These properties jointly with its established low index of toxicity in studies of unique and repeated doses (Garrido et al., 2007; Garrido et al., 2009) and its lack of genotoxicity (Rodeiro et al., 2006) and teratogenicity (Gonzales et al., 2007) seem to discover a new therapeutic resource on which the efforts have been centred for its clinical evaluation but more clinical evidences are necessary to expand its medical uses.

The aim of the present report of cases was to determine the possible effects and safety of MSBE (as Vimang tablets and compresses) in acute HZ patients. We propose that Vimang's formulations could be introduced as a new therapeutic agent in neuropathic pain. Afterwards, a controlled clinical trial is necessary to confirm this hypothesis.

\section{Materials and Methods}

\section{Subjects}

Twelve acute herpetic neuralgia patients were recruited from the Pain Clinic of 10 de Octubre Hospital, during the period of January-June, 2007. The study was approved by the Ethic Committee from this hospital and the Centre of Pharmaceutical Chemistry in accord with the Helsinki Declaration (Protocol Number: SC00307). Written informed consent was obtained for each patient after being fully informed of the study details.

\section{Study design}

To carry out this report of cases an open uncontrolled trial was conducted in acute $\mathrm{HZ}$ patients, adults of either sex (ten female and two male), that included patients with acute herpetic neuralgia (Dworkin et al., 2008), between 0 and 7 days of evolution. The intensity of initial pain accepted was 4 or more on a 10-point scale measured (Likert scale). Patients that received treatment with antiviral, opioid drugs and immunosuppressive agents until six months prior to the studies were excluded. Patients were excluded if they suffered from active malignancy. The primary outcome measure was the change in average daily pain score (ADPS) using a Likert scale (baseline week versus final week of study). This numeric scale is an established, validated, self report measure of pain intensity, 0 indicate the absence of pain and 10 the pain unbearable (Rice \& Maton, 2002). The patients evaluated individually the pain that corresponded to the previous $24 \mathrm{~h}$ in the morning and the initial score consisted of the average of pain daily registered in the week prior to the beginning of the study. The final score was the average of the daily pain registered in the week before of the medical visit at the thirty days. Although, the patients were evaluated at the sixty days, one month after they finished their treatment, with the purpose of evaluating the possible progress to PHN, as a complication of acute HZ. The outcomes were evaluated before the treatment, once a week until the end. In all cases information on dosage and frequencyadministration of the accepted analgesic drugs was collected.

\section{Drugs used in the study}

The industrial MSBE is obtained by decoction of the stem bark using water as a solvent with subsequent concentration, drying and homogenization to yield between 10 and $15 \%$ of a homogeneous brown powder (30-60 $\mu \mathrm{m}$ particle size), which melts with decomposition from 215 to $218^{\circ} \mathrm{C}$. This active principle is used to produce coated Vimang ${ }^{\circledR}$ tablets $(300 \mathrm{mg})$ which have been protected by patent and registered as phytodrug, food supplement or cosmetic by the Cuban health regulatory agencies (Núñez-Sellés et al., 2002). To prepare the compresses the solid extract was dissolved to $2 \%$ in distilled water and sterilized in the Centre of Pharmaceutical Chemistry.

\section{Treatments}

The patients received a daily dose of $1800 \mathrm{mg}$ of extract (two coated Vimang tablets, $300 \mathrm{mg}$ each, three times daily before meals). In addition to the 
tablets, compresses were utilized containing MSBE $2 \%$ dissolution on skin lesions three times daily. The treatment was performed for thirty days. The initial administration of amitriptyline at low doses (10-25 $\mathrm{mg} / \mathrm{d}$ ) associated to Vimang tablets was accepted. The antidepressant could be retired according to the patient's pain progress and this constituted a control outcome in the study. The administration of analgesic rescue dosage (dypirone) was also controlled.

\section{Statistical analysis}

Data were analyzed using the statistical program Graph Pad Prism 5. The difference between the mean of each outcome in 6 sites was evaluated using one way analyses of variance (ANOVA) followed by Bonferroni's post hoc test. The results are expressed as the mean \pm standard error of the mean (SEM). Values of $p<0.05$ were considered statistically significant.

\section{Results}

The mean of initial ADPS according to the Likert scale was 8 points. Subsequently, the patients were affected by severe pain at the beginning of the study. The mean age was between 50 and 59 years $(49 \%)$ and the females were predominantly affected $(83 \%)$. On the other hand, the topographic localization of injuries was observed in both thoracic and lumbar segments $(33 \%)$ with similar frequency. The cervical dermatomes were affected $17 \%$ as trigeminal nerve. The majority of patients were sent to the Pain Clinic about $0-3$ days of disease progression $(66.6 \%)$ and the rest between 4-7 days (33.3\%). The patients decreased significantly the average daily pain score from week $1(p<0.001)$ with respect to baseline data. This effect was maintained until the last evaluation at the day 60 (Figure 1). At the beginning of the study, eight patients combined Vimang with amitriptyline and four patients determined voluntarily not to utilize this drug. They retired the antidepressant in agreement with their pain progress, and the final daily dosage for amitriptyline at the sixty days, was decreased significantly $(p<0.01)$ with respect to the initial daily dosage. In addition, eight patients required rescue dosages with analgesics. According with Figure 2, the analgesic rescue dosages decreased significantly too at the end $(p=0.0035)$, this change was significant from the day $21(p<0.05)$.

\section{Discussion}

This study was performed to collect the preliminary information on the possible analgesic efficacy and safety of Vimang in patients with acute herpetic neuralgia. The dose used $(600 \mathrm{mg} / 8 \mathrm{~h})$ was

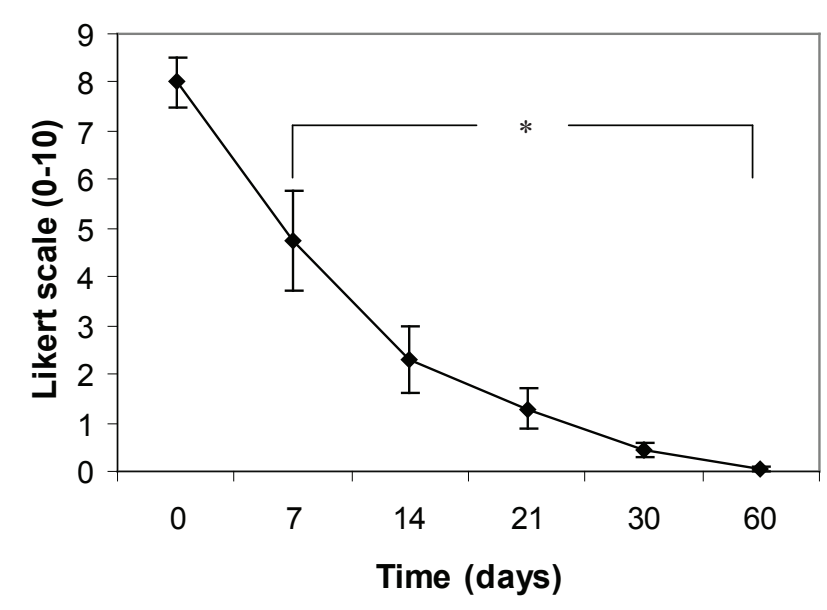

Figure 1. Change in average daily pain score (ADPS) in acute herpes zoster patients treated with Vimang's formulations. The results are presented as mean \pm SEM. ${ }^{*} p<0.05$ indicates significant differences with respect to baseline valour.

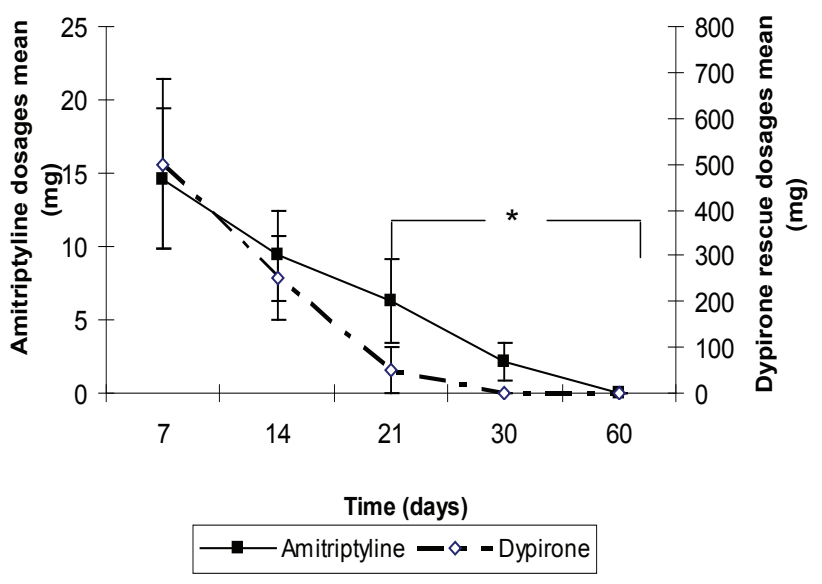

Figure 2. Concomitants drugs (analgesics and antidepressants) in acute herpes zoster patients treated with Vimang's formulations. The results are presented as mean \pm SEM. ${ }^{*} p<0.05$ indicates significant differences with respect to baseline valour.

selected according to ethno-medical studies, case reports and clinical trials performed before successfully (Perez et al., 2003; Guevara et al., 2004; Núñez et al., 2007; Garrido-Suárez et al., 2007; Garrido-Suárez et al., 2009; Valverde et al., 2009) and without adverse effects. The duration of treatment (30 days) was selected according to the fist point of recent findings in this disease that provides support for the validity of the three phases of zoster-associated pain: (1) acute herpetic neuralgia defined as pain that occurs within 30 days after rash onset; (2) sub-acute herpetic neuralgia defined as pain that persists beyond the acute phase but that resolves before the diagnosis of post-herpetic neuralgia (PHN) can be made; and (3) PHN defined as pain that persists 120 days or more after rash onset 
(Dworkin et al., 2008).

An important point by this report of cases was that the recruitment of the acute $\mathrm{HZ}$ patients was early and the precocity of treatment is critical in its results, as reported in other studies (Wu \& Raja, 2008). The majority of patients had 0-3 days (66.6\%) and 4-7 days (33.3\%) of evolution when they were remitted to Pain Clinic. Then, the analgesic, anti-inflammatory, antiviral and neuroprotective activity of Vimang formulations, introduced an early phase of this disease; as well as its antioxidant and immunomodulatory properties, could prevent PHN, the more common and dreaded complication of HZ. The treatment with Vimang tablets and its association to low doses of amitriptyline decreased the ADPS in patients with acute HZ from day 7 of starting the therapy. This effect was increased after day 14 until the end (Figure 1). In this time point, seven patients that associated amitriptyline with Vimang and the eight patients that utilized dypirone as analgesic rescue reduced their doses with respect to the beginning of the study. These results could be in relation with a major analgesic effect of Vimang tablets about fourteen days after the beginning of treatment (Núñez-Sellés et al., 2007; Garrido-Suárez et al., 2010). In preclinical studies, the exclusive inhibition of phase II of formalin $1 \%$ test for the MSBE is an element that suggests its capacity to modulate pathological and persistent painful status more than acute nociceptive pain (Garrido et al., 2001). It has been established that ROS play a role in this model, in peripheral sites their action may be more important mediating the acute phase; whereas in spinal site is the key mediating phase II (Hacimuftuoglu et al., 2006). The mechanisms of phase II are dose-related over range $0.5-5 \%$ and the participation of glutamate-NMDAnitric oxide synthase (NOS)-nitric oxide (NO) pathway in the spinal neuronal changes has been demonstrated (Coderre et al., 1990; Okuda et al., 2001). Moreover, the $\mathrm{Ca}^{2+}$ influx induced for NMDA activation produces enzymatic cascades, which finally evokes the release of prostaglandins too. Subsequently, the selective effect of cyclooxygenase (COX) and NOS inhibitors as well as NMDA antagonists in this phase and in neuropathic pain models are recognized (Vetter et al., 2001). In addition, it has been assumed that elevated levels of ROS play an important role in the phosphorylation of NMDA receptor subunit 1 (pNR1) through to protein kinases $\mathrm{A}$ and $\mathrm{C}$ (PKA and PKC) activation in the spinal cord (Kim et al., 2006; Gao et al., 2007). MSBE exhibits a potent antioxidant effect depending on its free radical scavenging and iron-complexing abilities (NúñezSellés et al., 2007). In acute HZ the pain responds to inflammatory and neuropathic mechanisms (Oaklander, 2008). A decisive contribution to this effect could be the modulatory effect of extract on pro-inflammatory cytokines, associated to the inhibition of inducible nitric oxide synthase (iNOS) and COX-2 expressions, secretory phospholipase $\mathrm{A}_{2}\left(\mathrm{PLA}_{2}\right)$ activity modulation and in down stream the activation of arachidonic acidderived species biosynthesis (Garrido et al., 2004; Garrido et al., 2005; Garrido et al., 2006). These effects could be the result of actions exerted by the different polyphenolic species included into the extract, specially the mangiferin (Leiro et al., 2004a). But, the selective prevention of the expression of inflammation-related genes by means of nuclear transcription factor kappa $\mathrm{B}(\mathrm{NF}-\kappa \mathrm{B})$ translocation inhibition is the key in its primary anti-inflammatory effect (Leiro et al., 2004b; Garrido et al., 2005). NFאB regulates the expression of several proteins involved in neural plasticity and this transcription factor is a key in the regulation of the inflammatory process in reactive glial cells (Manning, 2006); then its inhibition in acute HZ could prevent other heterogenic and complex mechanisms leading to PHN. In correspondence, a neuroprotective effect by MSBE has been reported (Lemus-Molina et al., 2009).

On the other hand, although, the antiviral activity of MSBE on VZV is not demonstrated, studies in vitro established its effect on herpes simplex type 1 (VHS-I) (EC50) of 53.4 $\pm 4.5 \mu \mathrm{g} / \mathrm{mL}$ (Carballo et al., 2002). VZV and VHS types I and II are members of the herpes virus $\alpha$-subfamily, with neurotropic characteristics. These viruses have in common several properties and establish latent infection in dorsal root ganglia (DRG) (Quinn et al., 2000). The favourable response in these patients, ethno-medical experience and preliminary reports suggest that MSBE could have similar activity (Álvarez et al., 2002; NúñezSellés et al., 2007). Besides, it is observed that once Vimang treatment started, the new sprouting of skin lesions were inhibited. It is of particular interest that $66.6 \%$ of patients beginning the treatment between 0-3 days, moment that is recognized for intense viral proliferation and thus is accepted that the antiviral drugs are effective (Oaklander, 2008; Wu \& Raja, 2008). Several investigations have documented its potentiality to prevent PHN, and suggest that early combination of amitriptyline and acyclovir could prevent the neural injury and central sensitization (Wu \& Raja, 2008). In the present study, the patients were evaluated a month post-treatment and none presented sub-acute herpetic neuralgia. In line with these facts, it is accepted that the basic helix-loop-helix (bHLH) protein encoded for immediate early gene 62 (IE62) has been implicated as an important regulatory element for VZV. It has been suggested that the bHLH protein family may play a major role in neuron specific gene expression, like regulation of neuropeptide genes expression in sensory ganglia and viral replication (Quinn et al., 2000). There is also evidence that bHLH molecules are important to modulate to calcitonin gene-related peptide. In 
addition, immunohistochemical analyses of DRG in model of chronic VZV in rodents, showed the presence of IE62 co-expressed with markers of A and C afferent sensory neurons. There was increased expression of neuropeptide Y, galanin, Nav1.3 and Nav1.8 sodium channels and $\alpha 2 \delta 1$ calcium channel in correlation with behavioural hyperalgesia (Garry et al., 2005). Mangiferin, a major component of MSBE, inhibits basic helix-loop-helix leucine zipper protein (bHLHZip) gene expression in activated mouse macrophages, in addition to several genes involved in the NFאB signal transduction pathway (Leiro et al., 2004b).

The topical agents play a pivotal role in the acute HZ treatment, and Vimang dissolution 2\% was accepted by the patients and, like the tablets, this formulation was not associated with adverse effects. The cutaneous rash presented a normal course for this auto-limited disease (Dworkin et al., 2008). None of the patients showed secondary bacterial infections and hypertrophic scars.

Patients with acute $\mathrm{HZ}$ neuralgia that received Vimang formulations during thirty days $(600 \mathrm{mg} / 8 \mathrm{~h})$ relieved pain and none showed an evolution to postherpetic neuralgia. There was also a significant reduction of concomitant analgesic or antidepressant drugs and no adverse events were reported.

Although the sample size is very small and therefore generalization is difficult, these results suggest that Vimang supplementation might be beneficial to prevent and treat neuropathic pain. Nevertheless, more controlled clinical evidence, is necessary to expand its medical uses.

\section{Acknowledgments}

Special thanks to Prof. Leticia Pérez and Jorge Conde Garrido for advice on correct use of the English language. Thanks to Laboratorios Farmacéuticos "Oriente", Cuba, and MSc, Ing. Zoe Lemus for provide Vimang's tablets. This study was financed in part by projects 004032338 (CITMA, Cuba) and 3315 (UCN, Chile).

\section{References}

Álvarez A, Guevara M, Riaño A, Garrido G, Delgado R 2002. Eficacia del tratamiento con extracto de Mangifera indica L. (VIMAG: crema 1,2\% y tabletas $150 \mathrm{mg}$ ) sobre el Herpes zoster. Presentación de un caso. Rev Cubana Farm 36: 171-173.

Carballo MT, Echemendía O, García M, Bolaños G, Monteagudo R, Lago V, Márquez L, Garrido G, Delgado R 2002. Estudio antiviral in vitro de un extracto proveniente de la Mangifera indica L frente al Herpes simple tipo I. Rev Cubana Farm 36: 71-73.

Coderre TJ, Vaccarino AL, Melzack, R 1990. Central nervous system plasticity in the tonic pain response to subcutaneous formalin injection. Brain Res 535 : 155-158.

De Leo JA, Tawfik VL, La Croix-Fralish ML 2006. The tetrapartite synapse; path to CNS sensitization and chronic pain. Pain 122: 17-21.

Dworkin RH, Gnann JW, Oaklander AL, Raja SN, Schmader KE, Whitley RJ 2008. Diagnosis and assessment of pain associated with Herpes zoster and postherpetic neuralgia. J Pain 9: 37-44.

Gao X, Kim HK, Cheng JM, Cheng K 2007. Reactive oxygen species (ROS) are involved in enhancement of NMDA-receptor phosphorylation in animal models of pain. Pain 131: 262-271.

Garrido G, Blanco M, Sancho R, Macho A, Delgado R, Muñoz E 2005. An aqueous stem bark extract of Mangifera indica $\left(\right.$ Vimang $\left.^{\mathbb{R}}\right)$ inhibits $\mathrm{T}$ cell proliferation and TNF-induced activation of nuclear transcription factor NF-kappaB. Phytother Res 19: 211-215.

Garrido G, Delgado R, Lemus Y, Rodríguez J, García D, Núñez AJ 2004. Protection against septic shock and suppression of tumor necrosis factor alpha and nitric oxide production on macrophages and microglia by a standard aqueous extract of Mangifera indica L. $\left(\right.$ Vimang $\left.^{\circledR}\right)$ : role of mangiferin isolated from the extract. Pharmacol Res 50: 165-172.

Garrido G, González D, Delporte C, Backhouse N, Quintero G, Núñez AJ, Morales MA 2001. Analgesic and antiinflammatory effects of Mangifera indica L. extract (Vimang). Phytother Res 15: 18-21.

Garrido G, González D, Lemus Y, Delporte C, Delgado R 2006. Protective effects of standard extract of Mangifera indica $\mathrm{L}\left(\right.$ Vimang $\left.^{\circledR}\right)$ against mouse ear edema and its inhibition of eicosanoid production in $\mathrm{J} 774$ murine macrophages. Phytomedicine 13: 412-418.

Garrido G, Sánchez GM, Andreu GP, Rivera DG, Casaña PH, Guerra RR, García MG, Hernández RD; NúñezSellés AJ 2007. Recent advances in the research \& development of an aqueous stem bark extract obtained from Mangifera indica L. In Capasso A (ed) Recent developments in medicinal plant research. Kerala: Research Signpost, p. 169-192.

Garrido G, Rodeiro I, Guerra E, Hernández I, González RM, García G, Pérez G, Delgado R 2009. In vitro and in vivo acute studies of Mangifera indica L. extract (Vimang $^{\circledR}$ ), a new antioxidant natural product. Drug Chem Toxicol 32: 53-58.

Garrido-Suárez B, Bosch-Váldes F, Garrido-Garrido G, Delgado-Hernández R, Porro-Novo JN, Manero Torres JM 2007. Utilidad del extracto de Mangifera indica L $\left(\right.$ VIMANG $\left.^{\circledR}\right)$ en el Síndrome Doloroso Regional Complejo. A propósito de un caso. Rev Soc Esp Dolor 14: 494-500.

Garrido-Suárez B, Rabí MC, Bosch F, Garrido-Garrido G, Delgado-Hernández R 2009. Introducción de la suplementación con Vimang ${ }^{\circledR}$ en el síndrome doloroso regional complejo: experiencia en 15 pacientes. Rev Soc Esp Dolor 16: 87-96.

Garrido-Suárez BB, Garrido G, Delgado R, Bosch F, Rabí MC 2010. A Mangifera indica L. extract could be used to treat neuropathic pain and implication of mangiferin. 
Molecules 15: 9035-9045.

Garry EM, Delaney A, Anderson HA, Sirinathsinghji EC, Clapp RH, Martin WJ, Kinchington PR, Krah DL, Abbadie C, Fleetwood-Walker SM 2005. Varicella zoster virus induces neuropathic changes in rat dorsal root ganglia and behavioural reflex sensitization that is attenuated by gabapentin or sodium channel blocking drugs. Pain 118: 97-111.

González JE, Rodríguez MD, Rodeiro I, Morffi J, Guerra E, Leal F, García H, Goicochea E, Guerrero S, Garrido G, Delgado R, Núñez-Selles AJ 2007. Lack of in vivo embryotoxic and genotoxic activities of orally administered stem bark aqueous extract of Mangifera indica L. $\left(\right.$ Vimang $\left.^{\circledR}\right)$. Food Chem Toxicol 45: 25262532.

Guevara M, Garrido G, Rodríguez PC, Riaño A, Álvarez A, Grupo de APS del Policlínico "Elpidio Berovides", Delgado R, Núñez Sellés AJ 2007. Effect of the antioxidant crem Vimang ${ }^{\circledR}$ on dermatological diseases. Latin Amer J Pharmacy 26: 237-242.

Guevara M, González S, Álvarez A, Riaño A, Garrido G, Nuñez AJ 2004. Uso etnomédico de la corteza de Mangifera indica L. en Cuba. Rev Cubana Plant Med 9: 1-9.

Hacimuftuoglu A, Handy CR, Goettl VM, Lin CG, Dane S, Stephens Jr RL 2006. Antioxidants attenuate multiple phases of formalin-induced nociceptive response in mice. Behav Brain Res 173: 211-216.

Kim HK, Kim JH, Gao X, Znou JL, Lee I, Cheng K, Cheng JM 2006. Analgesic effect of vitamin E is mediated by reducing central sensitization in neuropathic pain. Pain 122: 53-62.

Kim HK, Park SK, Zhou JL, Taglialatela G, Cheng K, Coggeshall RE, Chung JM 2004. Reactive oxygen species (ROS) play an important role in a rat model of neuropathic pain. Pain 111: 116-124.

Kotani N, Kudo R, Sakurai Y, Sawamura D, Sessler DI, Okada H, Nakayama H, Yamagata T, Yasujima M, Matsuki A 2004. Cerebrospinal fluid interleukin 8 concentrations and the subsequent development of postherpethic neuralgia. Am J Med 116: 318-324.

Leiro J, Arranz JA, Yáñez M, Ubeira FM, Sanmartín ML, Orallo F 2004a. Expression profiles of genes involved in the mouse nuclear factor-kappa B signal transduction pathway are modulated by mangiferin. Int Immunopharmacol 4: 763-778.

Leiro J, García D, Arranz JA, Delgado R, Sanmartín ML, Orallo F 2004b. An Anacardiaceae preparation reduces the expression of inflammation-related genes in murine macrophages. Int Immunopharmacol 4: 991-1003.

Lemus-Molina Y, Sánchez-Gómez MV, Delgado-Hernández $\mathrm{R}$, Matute C 2009. Mangifera indica L extract attenuates glutamate-induced neurotoxicity on rat cortical neurons. Neurotoxicology 30: 1053-1058.

Manning DC 2006. The role of neuroimmune activation in chronic neuropathic pain and new targets for therapeutic intervention. In Campbell JN, Basbaum AI, Dray A, Dubner R, Dworkin RH, Sang ChN (eds.) Emerging strategies for the treatment of neuropathic pain. Seattle: IASP Press, p.161-192.
Núñez AJ, Guevara A, Alvarez A, Pardo G 2007. Experiencias de la terapia antioxidante con Vimang en la atención primaria de salud en Cuba. Rev Cubana Salud Publica 33: 1-6.

Núñez-Sellés AJ, Delgado-Hernández R, Garrido-Garrido G, González-Rivera D, Guevara-García M, PardoAndreu GL 2007. The paradox of natural products as pharmaceutical. Experimental evidences of a mango stem bark extract. Pharmacol Res 55: 351-358.

Núñez-Sellés AJ, Páez-Betancourt E, Amaro-González D, Acosta-Esquijarosa J, Agüero-Agüero J, CapoteHernández R, Gárciga-Hernández MR, MoralesLacárrere IG, García-Pulpeiro O, Garrido-Garrido G, Martinez-Sánchez G, Morales-Segura MA 2002. Composiciones farmacéuticas y suplementos nutricionales a partir de extractos de Mangifera indica L. Oficina Cubana de la Propiedad Industrial. Patent No. 203/98, Havana, Cuba, October 30, 2002.

Oaklander AL 2008. Mechanisms of pain and itch caused by Herpes zoster (Shingles). J Pain 9: 10-18.

Okuda K, Sakurada Ch, Takahashi M, Yamada T, Sakurada $\mathrm{T}$ 2001. Characterization of nociceptive responses and spinal releases of nitric oxide metabolites and glutamate evoked by different concentrations of formalin in rats. Pain 92: 107-115.

Pardo-Andreu GL, Philip SJ, Riaño A, Sánchez C, Viada C, Núñez-Sellés AJ, Delgado R 2006. Mangifera indica L. (Vimang) protection against serum oxidative stress in elderly humans. Arch Med Res 37: 158-164.

Pérez L, Resik S, Cancio R, Robaina M, Gil L 2003. Efectos del Vimang sobre algunos marcadores de progresión de la infección por VIH-1 en pacientes cubanos. Rev Cubana Med Trop 55: 115-118.

Quinn JP, Dalziel RG, Nash AA 2000. Herpes virus latency in sensory ganglia - a comparison with endogenous neuronal gene expression. Prog Neurobiol 60: 167179.

Rice AS, Maton S 2002. Gabapentin in postherpetic neuralgia a randomised double blind, placebo controlled study. Pain 94: 215-224.

Rodeiro I, Cancino L, González J, Morffi J, Garrido G, González MR, Núñez A, Delgado R 2006. Evaluation of genotoxic potential of Mangifera indica L. extract (Vimang), a new antioxidant product with antioxidant activity. Food Chem Toxicol 44: 1707-1713.

Rowbotham MC, Petersen KL 2001. Zoster-associated pain and neural dysfunction. Pain 93: 1-5.

Steiner I, Kennedy PGE, Pachner AR 2007. The neurotropic herpes viruses: Herpes simplex and varicella-zoster. Lancet Neurol 6: 1015-1028.

Valverde S, Duarte EM, Ducangé D, Garrido G, GarcíaRivera D, Jáuregui U, Garrido B 2009. Utilidad de las formulaciones Vimang ${ }^{\circledR}$ en pacientes con osteoartrosis de rodilla. Rev Soc Esp Dolor 16: 32-41.

Vetter G, Geisslinger G, Tegeder I 2001. Release of glutamate, nitric oxide and prostaglandin E2 and metabolic activity in the spinal cord of rats following peripheral nociceptive stimulation. Pain 92: 213-218.

$\mathrm{Wu}$ CL, Raja SN 2008. An update on the treatment of postherpetic neuralgia. J Pain 9: 19-30. 


\section{*Correspondence}

Beatriz Garrido-Suárez

Laboratorio de Farmacología Molecular, Centro de Investigación y Desarrollo de Medicamentos

Ave. 26 No. 1605 e/ Boyeros y Puentes Grandes, Nuevo

Vedado, Plaza, Apdo. Postal 10600 La Habana, Cuba

beatriz.garrido@infomed.sld.cu 